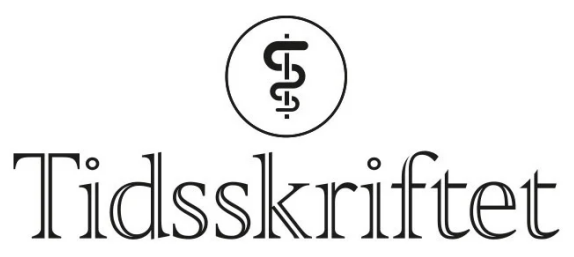

DEN NORSKE LEGEFORENING

\title{
Bruk av S1ooB ved akutte hodeskader
}

\author{
FRA LABORATORIET
}

GUNHILD ØYGARD FOSSE

gunhild.oygard.fosse@unn.no

Gunhild Øygard Fosse er lege i spesialisering i medisinsk biokjemi og konstituert overlege ved Laboratoriemedisin, Universitetssykehuset Nord-Norge.

Forfatteren har fylt ut ICMJE-skjemaet og oppgir ingen interessekonflikter.

\section{INGRID OPHEIM ØLNESS}

Ingrid Opheim Ølness er lege i spesialisering i medisinsk biokjemi og konstituert overlege ved Laboratoriemedisin, Universitetssykehuset Nord-Norge.

Forfatteren har fylt ut ICMJE-skjemaet og oppgir ingen interessekonflikter.

\section{Når bør serummarkøren S1ooB benyttes ved akutte hodeskader? Hvilke begrensninger er det nyttig å vite om?}

Ved akutt skade på sentralnervesystemet frigjøres proteinet S1ooB fra gliaceller til blodet. Analyse av S10oB ble implementert i Skandinaviske retningslinjer for akutt håndtering av voksne pasienter med minimal, lett eller moderat hodeskade i 2013 (1). Analysen anbefales som et alternativ til CT-undersøkelse hos en subgruppe pasienter med lett hodeskade, og skal identifisere dem som på grunn av høy risiko for å utvikle traumatisk intrakranialt hematom bør undersøkes med CT.

For voksne pasienter ( $\geq 18$ år) med lett hodeskade og lav risiko for intrakranial skade anbefales analyse av S10oB som primærdiagnostikk (tabell 1) (1). Blodprøven må tas innen seks timer etter skaden grunnet kort halveringstid og risiko for falskt negativt resultat. $\mathrm{S} 100 \mathrm{~B}<0,10 \mu \mathrm{g} / \mathrm{L}$ tilsier lav risiko for skade som krever videre utredning og/eller behandling, mens CT-undersøkelse eller innleggelse til observasjon anbefales ved serumnivå $\geq 0,10 \mu \mathrm{g} / \mathrm{L}$. Ved grenseverdi o,10 $\mu \mathrm{g} / \mathrm{L}$ har S10oB en negativ prediktiv verdi for traumatisk intrakranial skade på rundt $99 \%(1)$, mens positiv prediktiv verdi avhenger av pretest-sannsynlighet, og dermed korrekt indikasjon for rekvirering av testen.

\section{Tabell 1}

Skjematisk oversikt over risikofaktorer og tiltak ved lett hodeskade med lav, middels og høy risiko. Utdrag fra flytskjemaet publisert i Skandinaviske retningslinjer for akutt håndtering av voksne pasienter med minimal, lett eller moderat hodeskade (1).

\begin{tabular}{|lll|}
\hline Glasgow-skala og risikofaktorer & Risiko & Tiltak \\
\hline
\end{tabular}




\begin{tabular}{|c|c|c|}
\hline Glasgow-skala og risikofaktorer & Risiko & Tiltak \\
\hline GCS-skår 14 eller 15 og en av de følgende: & \multirow[t]{3}{*}{ Lav } & \multirow{3}{*}{$\begin{array}{l}\text { Hvis }<6 \text { timer etter } \\
\text { hodeskade, ta S100B } \\
\text { Hvis } \geq 6 \text { timer eller } \\
\text { ekstrakranial skade, ta } \\
\text { CT }\end{array}$} \\
\hline Mistenkt/bekreftet bevissthetstap & & \\
\hline Gjentatte brekninger ( $\geq 2$ episoder) & & \\
\hline GCS-skår $14-15$ og alder $\geq 65$ år samt platehemmere & Middels & $\begin{array}{l}\text { CT eller observasjon } \\
\geq 12 \text { timer }\end{array}$ \\
\hline GCS-skår 14-15 og en av de følgende: & \multirow[t]{6}{*}{ Høy } & \multirow[t]{6}{*}{ CT } \\
\hline Posttraumatisk epilepsianfall & & \\
\hline Fokale nevrologiske utfall & & \\
\hline Kliniske tegn til skallebrudd & & \\
\hline Shuntbehandlet hydrocefalus & & \\
\hline $\begin{array}{l}\text { Antikoagulasjonsbehandling eller } \\
\text { koagulasjonsforstyrrelse }\end{array}$ & & \\
\hline
\end{tabular}

For pasienter med lett hodeskade og middels eller høy risiko, samt pasienter som på Glasgow-skalaen (Glasgow Coma Scale, GCS) skårer < 14 (moderat/alvorlig hodeskade), er CT-undersøkelse anbefalt som primærdiagnostikk, og S10oB skal ikke tas. Pasienter med minimal hodeskade, definert som GCS-skår 15 uten bevissthetstap, brekninger eller risikofaktorer, skal heller ikke testes med markøren (11). S1ooB er en uspesifikk markør som kan frigjøres til blodet også ved ekstrakranial skade (1). Serumnivået av S1ooB var forhøyet hos $29 \%$ av pasienter med isolerte bruddskader $(\underline{2})$. Analysen er derfor utelukket som primærdiagnostikk ved samtidig ekstrakranial skade. S1ooB frigjøres ved skade på gliaceller og vil derfor ikke alltid være forhøyet ved ekstraaksiale intrakraniale hematomer uten primær hjerneskade, for eksempel epiduralt hematom (3). Dette illustrerer viktigheten av å følge anbefalt bruk. S1ooB er ikke inkludert i retningslinjer for akutte hodeskader hos barn (4).

Ved vårt sykehus fant vi at omlag halvparten av S1ooB-prøver over en ettårsperiode var tatt på feil indikasjon (upubliserte tall). De vanligste årsakene var at prøven ble tatt på barn og pasienter med lett hodeskade med middels eller høy risiko, hvorav pasienter $\geq 65$ år som brukte platehemmere eller antikoagulasjon utgjorde flertallet. S1ooB ble også rekvirert hos pasienter med GCS-skår < 14, prøvetaking $\geq 6$ timer etter skaden og hos pasienter med minimal hodeskade. Vi fant at over $40 \%$ av voksne med negativ test likevel ble undersøkt med CT, mens $20 \%$ av de med positiv test ikke ble unders $ø$ kt. Dette sammenfaller med funn gjort ved et annet sykehus i landet (E. Dizerens, personlig meddelelse). Der S1ooB var tatt på korrekt indikasjon, fant vi at resultatet hadde betydning for videre oppfølging. Pasienter med $\mathrm{S}_{100 \mathrm{~B}}<0,10 \mu \mathrm{g} / \mathrm{L}$ ble i de fleste tilfeller ikke unders $\varnothing \mathrm{kt}$ med CT, mens de med resultat $\geq 0,10 \mu \mathrm{g} / \mathrm{L}$ gjennomgikk med få unntak CT-undersøkelse eller ble lagt inn til observasjon.

Forutsatt riktig bruk, kan S10oB bidra til å redusere unødvendige CT-undersøkelser og innleggelser. Manglende etterlevelse av etablerte anbefalinger for analysen kan medføre over- og underdiagnostikk og økt ressursbruk.

\section{LITTERATUR}

1. Sundstrøm T, Wester K, Enger M et al. Skandinaviske retningslinjer for akutt håndtering av voksne pasienter med minimal, lett eller moderat hodeskade. Tidsskr Nor Legeforen 2013; 133: E1-6. [PubMed] [CrossRef] 
2. Undén J, Bellner J, Eneroth M et al. Raised serum S10oB levels after acute bone fractures without cerebral injury. J Trauma 2005; 58: 59-61. [PubMed][CrossRef]

3. Morochovic R, Rácz O, Kitka M et al. Serum S1ooB protein in early management of patients after mild traumatic brain injury. Eur J Neurol 2009; 16: 1112-7. [PubMed][CrossRef]

4. Astrand R, Rosenlund C, Undén J. Scandinavian guidelines for initial management of minor and moderate head trauma in children. BMC Med 2016; 14:33. [PubMed][CrossRef]

Publisert: 3. mai 2021. Tidsskr Nor Legeforen. DOI: 10.4045/tidsskr.21.0157

(C) Tidsskrift for Den norske legeforening 2023. Lastet ned fra tidsskriftet.no 26. april 2023. 